\title{
School Education In Villages Near Kalisindh Thermal Power Project (Katpp), Jhalawar, Rajasthan
}

\author{
Ms. Reeta Karra, Dr. P. N. Mishra \\ Assistant Engineer, Service Building, H-II, Second Floor, Kalisindh Thermal Power Project, Near village \\ Undal, Rajasthan Rajya Vidyut Utpadan Nigam Limited, Jhalawar - 326023 (Raj.) India \\ Director, Deen Dayal Kaushal Kendra, Devi Ahilya Vishwavidhyalay, Takshshila Campus, Khandwa Road, \\ Indore - 452017 (M.P.) India \\ ${ }^{I}$ (Institute of Management Studies, Devi Ahilya Vishwavidhyalya, Indore, India) \\ ${ }_{2}^{2}$ (Director, Deen Dayal Kaushal Kendra, Devi Ahilya Vishwavidhyalya Indore, India)
}

\begin{abstract}
An industrial unit changes the socio-economic fabric of the vicinity. It gives some benefits to the area and posses certain problems. The thermal power plant named as Kalisindh Thermal Power Project constructed in State Rajasthan is no exception to this. For construction of this power project land of nearby villages viz Devri, Motipura, Nimoda, Singhania and Undal was acquired. Problems of school education in these villages have analyzed to know the difficulties faced by villagers for education of their children. A survey has been carried out on people living in these villages through a structured questionnaire to collect data. Convenience sampling is used for collection of data. Frequency, percentage, simple arithmetic mean and ANOVA are the statistical tools used for the analysis. With help of this study, it has been concluded that major problems faced by villagers regarding educational facilities are non availability of local teachers and their bad response, location of private school at distance; hence commuting is time consuming as well as hectic for children. Also distant private schools are expensive, so everyone can not afford them. This education remains a major social concern in the area.
\end{abstract}

Keywords: ANOVA, Convenience Sampling, Socio-Economic Fabric, Social concern.

\section{INTRODUCTION}

Education plays a very important role in our life. School education is basic for children and a necessary part of their life. It gives knowledge and develops better understanding towards life. Education influences our social life in so many ways. Without education life might be like an animal. Education is necessary to achieve goals successfully in life. Education also helps to build self confidence and motivate everyone leading an independent life. In school education teachers play a very important role to teach children basic education, role of courtesy and manners etc. Therefore, teachers should be dedicated to these goals. The Government Schools are not satisfactory. Private schools are expensive and located far away from villages. Everyone can not afford them. Peshkin $(1978,1982)$ showed how vital a school is to the survival of rural communities. He noted that schools serve as symbols of community autonomy, community vitality, community integration, personal control, personal and community tradition, and personal and community identity. PROBE Team (1999) stated that the extreme cases of teacher negligence were less devastating than the quiet inertia of the majority of teachers. In half of the sample schools, there was no teaching activity at the time of the investigators' visit. Inactive teachers were found engaged in a variety of pastimes such as sipping tea, reading comics, or eating peanuts, when they were not just sitting idle. Kalisindh thermal power plant constructed in state Rajasthan. It is located near village Undal approximately $15 \mathrm{~km}$ far from District Jhalawar. Construction of Kalisindh Thermal Power Plant was started in Oct 2009. For constructing this thermal power plant, land was acquired in the year 2008. During land acquisition, land of five villages i.e. Devri, Motipura, Nimoda, Singhania and Undal was also acquired, for which compensation was paid to villagers. A research on the socio-economic impact of Kalisindh thermal power project has been carrying out. As a part of this research problem in school education in these villages has been analysed. This paper presents the findings.

\section{LITERATURE REVIEW}

Good deal of literature is available related to this work. A few are presents below:-

Kingdon (1998) and Kingdon and Unni (2001) found that the education-wage relationship is convex in India, i.e. returns to secondary and higher education are significantly greater than to primary and middle levels of education. 
Kingdon and Muzammil (2003), estimated that average teacher salary rates rose by a remarkably high rate of 5 per cent per annum in real terms in the 22-year period between 1974 and 1996. Kingdon et. al. (2004) noted that while attendance rates themselves are not a guarantee of grade completion or of achieving minimum levels of learning, these are nevertheless highly encouraging trends. Hanushek (2005), summarised that a large body of evidence suggests that workers' productivity and earnings depend not only on years of education acquired but also on what is learnt at school. Kremer et. al (2005), surveyed and found that absence of teacher in rural India in 2003 made three unannounced visits to each one of 3700 schools in 20 major states of India. They found that, on average, 25 percent of teachers in government primary schools were absent from school on a given day. Secondly, and more disturbingly, even among teachers who were present, only about half were found engaged in teaching. Mehta (2005) found that in seven districts of Punjab, there were 3,058 private elementary (primary plus junior) schools, of which 86 per cent were unrecognized. Hanushek and Zhang (2006) confirmed significant economic returns to literacy for 13 countries on which literacy data were available. This evidence underlines the importance of ensuring that what schools do leads to learning achievement. Muralidharan and Kremer (2006) found in their national survey of 20 states, $51 \%$ of all private rural primary schools were unrecognized.

National data on learning achievement levels in ASER2005 (Pratham, 2006) found that private school students of grades 2 to 5 were $37.4 \%$ more likely than government school students to be able to read a text of grade 2 standard. They were also $50 \%$ more likely to be able to solve a 23 division problem (3 digits divided by 1 digit). Kingdon (2007), examined in his paper schooling access in terms of enrolment and school attendance rates, and schooling quality in terms of literacy rates, learning achievement levels, school resources, and teacher inputs. She also investigated the role of private schooling in India, examined the extent of growth of private schooling, surveyed evidence on the relative effectiveness and unit costs of private and public schools and discussed some major public education initiatives. The ASER survey (Pratham, 2007) shows that among the major Indian states, in Punjab, Haryana, and Kerala, the percentage of children attending private school increased by more than 10 percentage points between 2005 and 2006. The above citations stand testimony to the fact that school education has serious problem.

\section{OBJECTIVE}

This study is devoted to single objective of analysis of problems in school education for children in villages in the context of their response to KaTPP.

\section{RATIONALE}

Kalisindh Thermal Power Project is constructed near village Undal, Rajasthan. Few more villages are also situated in neighbouring area of this Thermal Power Project. No study has earlier been carried out to find out problems in school education facilities available for children living in these villages. This research is to analyze problems faced by villagers living in nearby villages to the Kalisindh Thermal Power Project for education facilities available for their children. The researcher has gone through exhaustive amount of literature available related to this field of study. Very little research in this field is carried out till now. This study is an endeavour to plug this gap.

\section{HYPOTHESIS}

Following Hypothesis has been framed and tested in the study:-

$\mathrm{H}_{01}$ : "There is no significant difference among the villagers with respect to non availability of educational facilities for their children".

$\mathrm{H}_{02}$ : "There is no significant difference among the villagers with respect to non availability of school in nearby vicinity".

$\mathrm{H}_{03}$ : "There is no significant difference among the villagers with respect to non availability of local teachers".

$\mathrm{H}_{04}$ : "There is no significant difference among the villagers with respect to non availability of books in nearby vicinity".

$\mathrm{H}_{05}$ : "There is no significant difference among the villagers with respect to non availability of private school in nearby vicinity".

$\mathrm{H}_{06}$ : "There is no significant difference among the villagers with respect to non availability of affordable private school".

$\mathrm{H}_{07}$ : "There is no significant difference among the villagers with respect to non availability of convenient mode of transportation for distance private school becomes hectic for children".

$\mathrm{H}_{08}$ : "There is no significant difference among the villagers with respect to long travelling time for distance private school".

$\mathrm{H}_{09}$ : "There is no significant difference among the villagers with respect to lack of teachers' good response". 


\section{RESEARCH METHODOLOGY}

The type of research used here is descriptive in nature. A survey of villagers living in five villages i.e. Devri, Motipura, Nimoda, Singhania and Undal have been carried out by filling a structured questionnaire form. Convenience sampling method was used for selection of villagers. As there is not much difference among the people of villages the Convenience sampling for this particular study is appropriate. Reliability analysis was done to identify internal consistency of the variables. Table -1 shows Cronbach's alpha value of the scale was found to be greater than 0.7. This shows adequate internal consistency. Frequency, percentage, simple arithmetic mean and ANOVA are the statistical tools used for the analysis.

\section{DATA ANALYSIS AND FINDINGS}

As the result of Data Analysis following findings have emerged:-Table - 2 shows that many respondents are satisfied with education facilities available near to their villages but few respondents are not satisfied with available education facilities. It infers that they expect better education facilities for their children. Table -3 shows problems faced by villagers with education facilities due to non availability of local teachers and their bad response, location of private school at distance; hence travelling is time consuming as well as hectic for children. Also distant private schools are expensive, so everyone can not afford them. It infers that if teachers are coming from far away for teaching in village, they might be already tired due to journey performed by them. Hence they cannot teach students with full energy and concentration.

\section{INTERPRETATION OF ANOVA}

The ANOVA table is interpreted as below:-

8.1. Non Availability of educational facilities

Table -4 shows that $\mathrm{f}$ value of interaction between the villages and Non Availability of educational facilities is 2.229 with degree of freedom 4 , which is not significant. It means that there is no significant difference in the villagers with respect to Non Availability of educational facilities for their children. In the light of this the null hypothesis namely "There is no significant difference among the villagers with respect to Non Availability of educational facilities for their children" is not rejected.

8.2. Non Availability of school in nearby vicinity

Table -4 shows that $\mathrm{f}$ value of interaction between the villages and problems/issues i.e. non availability of school in nearby vicinity is negligible, hence insignificant. It means that there is no significant difference in the villagers with respect to non availability of school in nearby vicinity. In the light of this the null hypothesis namely "There is no significant difference among the villagers with respect to non availability of school in nearby vicinity" is not rejected.

8.3. Non Availability of local teachers

Table -4 shows that $\mathrm{f}$ value of interaction between the villages and having non availability of local teachers is 5.575 with degree of freedom 4 , which is significant at the 0.01 level. It means that there is significant difference in the villagers with respect to non availability of local teachers. In the light of this the null hypothesis namely "There is no significant difference among the villagers with respect to non availability of local teachers" is rejected.

Further observations from table -5 are as follows:

i) Significant difference is found between the villagers of village Devri and Singhania at 0.05 level. Mean score of village Singhania is higher than that of Devri, so it can be concluded that more villagers in village Devri agreed about non availability of local teachers.

ii) Significant difference is found between the villagers of village Motipura and Singhania at 0.01 level. Mean score of village Singhania is higher than that of Motipura, so it can be concluded that more villagers in village Motipura agreed about non availability of local teachers.

iii) Significant difference is found between the villagers of village Nimoda and Singhania at 0.01 level. Mean score of village Singhania is higher than that of Nimoda, so it can be concluded that more villagers in village Nimoda agreed about non availability of local teachers.

iv) Significant difference is found between the villagers of village Singhania and Undal at 0.05 level. Mean score of village Singhania is higher than that of Undal, so it can be concluded that more villagers in village Undal agreed about non availability of local teachers.

8.4. Non availability of books in nearby vicinity

Table -4 shows that $\mathrm{f}$ value of interaction between the villages and non availability of books in nearby vicinity is 4.375 with degree of freedom 4 , which is significant at the 0.05 level. It means that there is significant difference in the villagers with respect to non availability of books in nearby vicinity. In the light of this the null hypothesis namely "There is no significant difference among the villagers with respect to non availability of books in nearby vicinity" is rejected. 
Further observations from table -5 are as follows:

i) Significant difference is found between the villagers of village Devri and Motipura at 0.01 level. Mean score of village Devri is higher than that of Motipura, so it can be concluded that more villagers in village Motipura agreed about non availability of books in nearby vicinity.

ii) Significant difference is found between the villagers of village Devri and Nimodaa at 0.01 level. Mean score of village Devri is higher than that of Nimoda, so it can be concluded that more villagers in village Nimoda agreed about non availability of books in nearby vicinity.

iii) Significant difference is found between the villagers of village Devri and Singhania at 0.01 level. Mean score of village Devri is higher than that of Singhania, so it can be concluded that more villagers in village Singhania agreed about non availability of books in nearby vicinity.

iv) Significant difference is found between the villagers of village Motipura and Undal at 0.05 level. Mean score of village Undal is higher than that of Motipura, so it can be concluded that more villagers in village Motipura agreed about non availability of books in nearby vicinity.

v) Significant difference is found between the villagers of village Nimoda and Undal at 0.05 level. Mean score of village Undal is higher than that of Nimoda, so it can be concluded that more villagers in village Nimoda agreed about non availability of books in nearby vicinity.

8.5. Non Availability of private school in nearby vicinity

Table -4 shows that $f$ value of interaction between the villages and non availability of private school in nearby vicinity is 6.633 with degree of freedom 4 , which is significant at the 0.01 level. It means that there is significant difference in the villagers with respect to non availability of private school in nearby vicinity". In the light of this the null hypothesis namely "There is no significant difference among the villagers with respect to non availability of private school in nearby vicinity" is rejected.

Further observations from table -5 are as follows:

i) Significant difference is found between the villagers of village Devri and Motipura at 0.01 level. Mean score of village Devri is higher than that of Motipura, so it can be concluded that more villagers in village Motipura agreed about non availability of private school in nearby vicinity.

ii) Significant difference is found between the villagers of village Devri and Nimoda at 0.01 level. Mean score of village Devri is higher than that of Nimoda, so it can be concluded that more villagers in village Nimoda agreed about non availability of private school in nearby vicinity.

iii) Significant difference is found between the villagers of village Devri and Singhania at 0.01 level. Mean score of village Devri is higher than that of Singhania, so it can be concluded that more villagers in village Singhania are agreed about non availability of private school in nearby vicinity.

iv) Significant difference is found between the villagers of village Devri and Undal at 0.01 level. Mean score of village Devri is higher than that of Undal, so it can be concluded that more villagers in village Undal agreed about non availability of private school in nearby vicinity.

8.6. Non Availability of Affordable private school

Table -4 shows that $f$ value of interaction between the villages and non availability of affordable private school is 3.091 with degree of freedom 4 , which is significant at the 0.05 level. It means that there is significant difference in the villagers with respect to non availability of affordable private school. In the light of this the null hypothesis namely "There is no significant difference among the villagers with respect to non availability of affordable private school" is rejected.

Further observations from table -5 are as follows:

i) Significant difference is found between the villagers of village Devri and Motipura at the 0.05 level. Mean score of village Devri is higher than that of Motipura, so it can be concluded that more villagers in village Motipura agreed about non availability of affordable private school.

ii) Significant difference is found between the villagers of village Motipura and Singhania at the 0.01 level. Mean score of village Singhania is higher than that of Motipura, so it can be concluded that more villagers in village Motipura agreed about non availability of affordable private school.

iii) Significant difference is found between the villagers of village Motipura and Undal at the 0.05 level. Mean score of village Undal is higher than that of Motipura, so it can be concluded that more villagers in village Motipura agreed about non availability of affordable private school.

iv) Significant difference is found between the villagers of village Nimoda and Singhania at the 0.01 level. Mean score of village Singhania is higher than that of Nimoda, so it can be concluded that more villagers in village Nimoda agreed about non availability of affordable private school.

v) Significant difference is found between the villagers of village Nimoda and Undal at the 0.05 level. Mean score of village Undal is higher than that of Nimoda, so it can be concluded that more villagers in village Nimoda agreed about non availability of affordable private school.

8.7. Non Availability of Convenient Mode of Transportation for Distance Private School 
Table -4 shows that $\mathrm{f}$ value of interaction between the villages and non availability of convenient mode of transportation for distance private school is 6.437 with degree of freedom 4 , which is significant at the 0.01 level. It means that there is significant difference in the villagers with respect to non availability of convenient mode of transportation for distance private school. In the light of this the null hypothesis namely "There is no significant difference among the villagers with respect to non availability of convenient mode of transportation for distance private school" is rejected.

Further observations from table -5 are as follows:

i) Significant difference is found between the villagers of village Devri and Singhania at the 0.01 level. Mean score of village Singhania is higher than that of Devri, so it can be concluded that more villagers in village Devri agreed about non availability of convenient mode of transportation for distance private school becomes hectic for children.

ii) Significant difference is found between the villagers of village Motipura and Singhania at the 0.01 level. Mean score of village Singhania is higher than that of Motipura, so it can be concluded that more villagers in village Motipura agreed about non availability of convenient mode of transportation for distance private school becomes hectic for children.

iii) Significant difference is found between the villagers of village Nimoda and Singhania at the 0.01 level. Mean score of village Singhania is higher than that of Nimoda, so it can be concluded that more villagers in village Nimoda agreed about non availability of convenient mode of transportation for distance private school becomes hectic for children.

iv) Significant difference is found between the villagers of village Singhania and Undal at the 0.01 level. Mean score of village Singhania is higher than that of Undal, so it can be concluded that more villagers in village Undal agreed about non availability of convenient mode of transportation for distance private school becomes hectic for children.

8.8. Long Travelling Time for Distance Private School

Table -4 shows that $\mathrm{f}$ value of interaction between the villages and long travelling time for distance private school is 4.939 with degree of freedom 4 , which is significant at the 0.01 level. It means that there is significant difference in the villagers with respect to long travelling time for distance private school. In the light of this the null hypothesis namely "There is no significant difference among the villagers with respect to long travelling time for distance private school" is rejected.

Further observations from table -5 are as follows:

i) Significant difference is found between the villagers of village Devri and Undal at the 0.01 level. Mean score of village Undal is higher than that of Devri, so it can be concluded that more villagers in village Devri agreed about long travelling time for distance private school.

ii) Significant difference is found between the villagers of village Motipura and Undal at the 0.01 level. Mean score of village Undal is higher than that of Motipura, so it can be concluded that more villagers in village Motipura agreed about long travelling time for distance private school.

iii) Significant difference is found between the villagers of village Nimoda and Undal at the 0.01 level. Mean score of village Undal is higher than that of Nimoda, so it can be concluded that more villagers in village Nimoda agreed about long travelling time for distance private school.

iv) Significant difference is found between the villagers of village Singhania and Undal at the 0.01 level. Mean score of village Undal is higher than that of Singhania, so it can be concluded that more villagers in village Singhania agreed about long travelling time for distance private school.

8.9. Lack of teachers' good response

Table -4 shows that $\mathrm{f}$ value of interaction between the villages and lack of teachers' good response is 3.229 with degree of freedom 4 , which is significant at the 0.01 level. It means that there is significant difference in the villagers with respect to lack of teachers' good response. In the light of this the null hypothesis namely "There is no significant difference among the villagers with respect to lack of teachers" good response" is rejected.

Further observations from table -5 are as follows:

i) Significant difference is found between the villagers of village Motipura and Singhania at the 0.01 level. Mean score of village Singhania is higher than that of Motipura, so it can be concluded that more villagers in village Motipura agreed about lack of teachers' good response.

ii) Significant difference is found between the villagers of village Motipura and Undal at the 0.05 level. Mean score of village Undal is higher than that of Motipura, so it can be concluded that more villagers in village Motipura agreed about lack of teachers' good response.

iii) Significant difference is found between the villagers of village Nimoda and Singhania at the 0.01 level. Mean score of village Singhania is higher than that of Nimoda, so it can be concluded that more villagers in village Nimoda agreed about lack of teachers' good response. 
iv) Significant difference is found between the villagers of village Nimoda and Undal at the 0.05 level. Mean score of village Undal is higher than that of Nimoda, so it can be concluded that more villagers in village Nimoda agreed about lack of teachers' good response.

\section{CONCLUSION AND SUGGESTIONS}

A thermal power plant was constructed in state Rajasthan. It is located near village Undal approximately $15 \mathrm{~km}$ far from District Jhalawar. For construction of this thermal power plant Rajasthan Rajya Vidyut Utpadan Nigam Limited acquired land of five villages i.e. Devri, Motipura, Nimoda, Singhania and Undal. A survey has been carried out for analyzing problems in school education for children in these villages. Villagers are facing problems with education facilities such as non availability of local teachers and lack of teachers' good response, location of private school at distance; hence travelling is time consuming as well as hectic for children. Also distant private schools are expensive, so everyone can not afford them.

Government shall propose an incentive schemes to motivate teachers for improving their dedication and response towards children. Private schools have opportunity to open branches of their school in vicinity of these villages so that villagers of these villages can take benefit of these schools for education of their children. Schools shall arrange training and motivation programs for teachers of local areas to educate children; they can devote more time with children.

\section{X. $\quad$ LIMITATIONS OF THE STUDY}

The study has following major limitations:-

- The study is limited to the villagers living in villages located near to the Kalisindh Thermal Power Plant only; therefore findings may not be valid for other areas.

- Non probabilistic Convenience sampling has been used for collecting primary data from villagers for the study and it has its own limitations.

- Results cannot be generalized.

\section{ACKNOWLEDGEMENT}

The authors thankfully acknowledge the critical input received from Dr. Pooja Jain, Asst. Professor, International Institute of Professional Studies, Devi Ahilya Vishwavidhyalay, Indore.

\section{REFERENCES}

[1]. Peshkin Alan, "Growing Up American: Schooling and the Survival of Community", Chicago: The University of Chicago Press, 1978.

[2]. Peshkin Alan, “The Imperfect Union”, Chicago: The University of Chicago Press, 1982.

[3]. Probe Team: "Public Report on Basic Education in India", Oxford University Press, New Delhi, 1999.

[4]. Kingdon G., "Does the Labour Market Explain Lower Female Schooling in India?", Journal of Development Studies, October, 1998, Vol. 35, No. 1, pg. 39-65.

[5]. Kingdon G. and Jeemol Unni. .Education and Women.s Labour Market Outcomes in India., Education Economics, August 2001, 9, No. 2: 173-195.

[6]. Kingdon G. G. and Muzammil, M., "The Political Economy of Education in India: Teacher Politics in Uttar Pradesh", Delhi, Oxford University Press, 2003.

[7]. Kingdon G., R. Cassen, K. McNay and L. Visaria, "Education and Literacy, Chapter in T. Dyson, R. Cassen, and L. Visaria (eds) Twenty-First Century India . Population, Economy, Human Development and the Environment", Oxford University Press, London, 2004.

[8]. Hanushek Eric, "The Economics of School Quality", German Economic Review, 2005, Vol. 6, Issue 3, pg. 269-286.

[9]. Kremer M., N. Chaudhury and F. H. Rogers, K. Muralidharan, and J. Hammer, "Teacher Absence in India: A Snapshot", Journal of the European Economic Association, 2005, Vol. 3, No. 2-3: 658-667.

[10]. Mehta A., "Elementary Education in Unrecognized Schools in India: A Study of Punjab Based on DISE 2005 Data", New Delhi, NIEPA, 2005.

[11]. Eric A. Hanushek \& Lei Zhang, "Quality-Consistent Estimates of International Returns to Skill," NBER Working Papers 12664, National Bureau of Economic Research, Inc., 2006.

[12]. Muralidharan K. and M. Kremer, "Private and Public Schools in Rural India", Mimeo, Harvard University, March 2006.

[13]. Pratham (2006), “ASER 2005 - Annual Status of Education Report”, Pratham, New Delhi, February 2006.

[14]. Kingdon Geeta Gandhi, "The progress of school education in India", Oxford Journals Social Sciences Oxford Review of Economic Policy, March 2007, Volume 23, Issue 2, pg. 168-195.

[15]. Pratham (2007), “ASER 2006 - Annual Status of Education Report”, Pratham, New Delhi, January 2007. 
Table - 1: Reliability Statistics

\begin{tabular}{|c|c|}
\hline Name of Village & Cronbach Alpha \\
\hline Devri & 0.735 \\
\hline Motipura & 0.771 \\
\hline Nimoda & 0.724 \\
\hline Singhania & 0.757 \\
\hline Undal & 0.809 \\
\hline
\end{tabular}

Appendix

Table - 2: Education facilities satisfaction / problems / issues

\begin{tabular}{|c|c|c|c|c|c|c|}
\hline \multirow{2}{*}{ Village } & \multicolumn{3}{|c|}{$\begin{array}{c}\text { Satisfied with education } \\
\text { facilities }\end{array}$} & \multicolumn{3}{|c|}{$\begin{array}{c}\text { Problems/issues with education } \\
\text { facilities }\end{array}$} \\
\hline & $\begin{array}{c}\text { Not applicable } \\
(\%)\end{array}$ & $\begin{array}{l}\text { Yes } \\
(\%)\end{array}$ & $\begin{array}{l}\text { No } \\
(\%)\end{array}$ & $\begin{array}{c}\text { Not applicable } \\
(\%)\end{array}$ & $\begin{array}{l}\text { Yes } \\
(\%)\end{array}$ & $\begin{array}{l}\text { No } \\
(\%)\end{array}$ \\
\hline Devri & 56 & 30 & 14 & 56 & 14 & 30 \\
\hline Motipura & 43 & 57 & 0 & 43 & 0 & 57 \\
\hline Nimoda & 63 & 37 & 0 & 63 & 0 & 37 \\
\hline Singhania & 62 & 22 & 16 & 62 & 14 & 24 \\
\hline Undal & 55 & 33 & 12 & 55 & 12 & 33 \\
\hline
\end{tabular}

Table - 3: Problems with education facilities

\begin{tabular}{|c|c|c|c|c|c|c|}
\hline Problems & $\begin{array}{c}\text { Most } \\
\text { Pressing } \\
(\%)\end{array}$ & $\begin{array}{c}\text { More } \\
\text { Pressing } \\
(\%)\end{array}$ & $\begin{array}{l}\text { Pressing } \\
\quad(\%)\end{array}$ & $\begin{array}{c}\text { Less } \\
\text { Pressing } \\
(\%)\end{array}$ & $\begin{array}{c}\text { Least } \\
\text { Pressing } \\
(\%)\end{array}$ & $\begin{array}{c}\text { None } \\
(\%)\end{array}$ \\
\hline $\begin{array}{c}\text { No school is } \\
\text { nearby vicinity }\end{array}$ & & & & & & 100 \\
\hline $\begin{array}{c}\text { Teachers are not } \\
\text { localize }\end{array}$ & 10 & & & & & 90 \\
\hline $\begin{array}{c}\text { Not availability of } \\
\text { books in nearby } \\
\text { vicinity }\end{array}$ & & & 6 & & 8 & 86 \\
\hline $\begin{array}{l}\text { No private school } \\
\text { is nearby vicinity }\end{array}$ & 4 & & 4 & 6 & & 86 \\
\hline $\begin{array}{l}\text { Distance private } \\
\text { school is too } \\
\text { expensive }\end{array}$ & & 2 & & 2 & 6 & 90 \\
\hline $\begin{array}{c}\text { Travelling for } \\
\text { private school is } \\
\text { hectic for children }\end{array}$ & & 2 & 2 & 2 & & 94 \\
\hline $\begin{array}{l}\text { Travelling for } \\
\text { private school is } \\
\text { time consuming }\end{array}$ & & & 2 & 2 & & 96 \\
\hline $\begin{array}{l}\text { Teachers response } \\
\text { is not good }\end{array}$ & & 10 & & & & 90 \\
\hline
\end{tabular}

Table - 3B: Village: Motipura

\begin{tabular}{|c|c|c|c|c|c|c|}
\hline Problems & $\begin{array}{c}\text { Most } \\
\text { Pressing } \\
(\%)\end{array}$ & $\begin{array}{c}\text { More } \\
\text { Pressing } \\
(\%)\end{array}$ & $\begin{array}{c}\text { Pressing } \\
(\mathbf{\%})\end{array}$ & $\begin{array}{c}\text { Less } \\
\text { Pressing } \\
(\%)\end{array}$ & $\begin{array}{c}\text { Least } \\
\text { Pressing } \\
(\%)\end{array}$ & $\begin{array}{c}\text { None } \\
(\%)\end{array}$ \\
\hline $\begin{array}{c}\text { No school is } \\
\text { nearby vicinity }\end{array}$ & & & & & & 100 \\
\hline $\begin{array}{c}\text { Teachers are not } \\
\text { localize }\end{array}$ & & & & & & 100 \\
\hline $\begin{array}{c}\text { Not availability of } \\
\text { books in nearby } \\
\text { vicinity }\end{array}$ & & & & & & 100 \\
\hline No private school & & & & & 100 \\
\hline
\end{tabular}




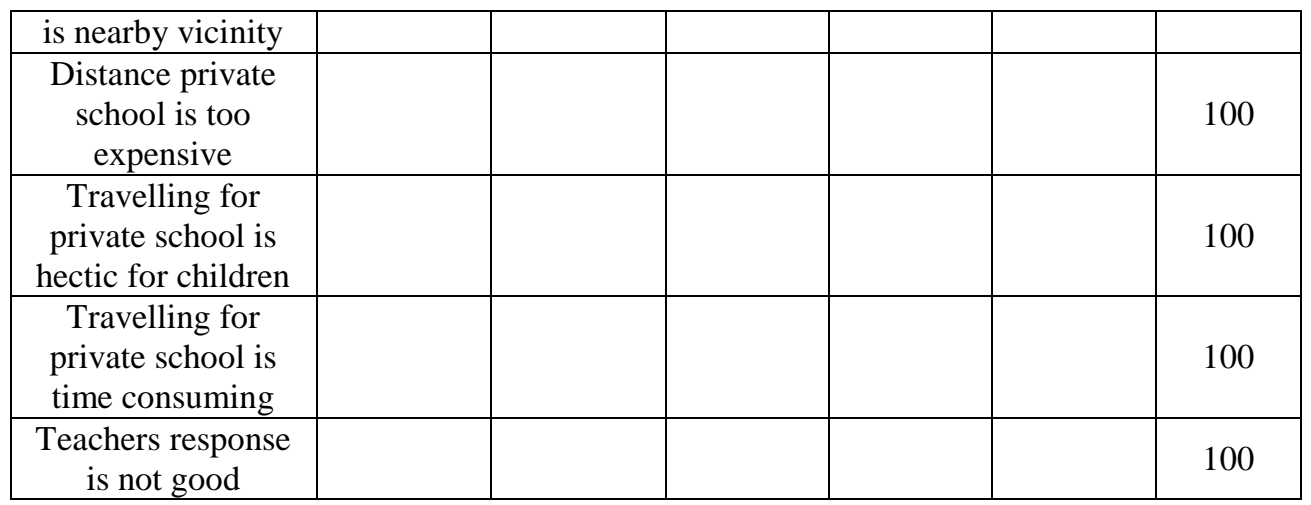

Table - 3C: Village Nimoda

\begin{tabular}{|c|c|c|c|c|c|c|}
\hline Problems & $\begin{array}{c}\text { Most } \\
\text { Pressing } \\
(\%)\end{array}$ & $\begin{array}{c}\text { More } \\
\text { Pressing } \\
(\mathbf{\%})\end{array}$ & $\begin{array}{c}\text { Pressing } \\
(\mathbf{\%})\end{array}$ & $\begin{array}{c}\text { Less } \\
\text { Pressing } \\
(\mathbf{\%})\end{array}$ & $\begin{array}{c}\text { Least } \\
\text { Pressing } \\
(\%)\end{array}$ & $\begin{array}{c}\text { None } \\
(\%)\end{array}$ \\
\hline $\begin{array}{c}\text { No school is nearby } \\
\text { vicinity }\end{array}$ & & & & 100 \\
\hline $\begin{array}{c}\text { Teachers are not } \\
\text { localize }\end{array}$ & & & & & 100 \\
\hline $\begin{array}{c}\text { Not availability of } \\
\text { books in nearby } \\
\text { vicinity }\end{array}$ & & & & & 100 \\
\hline $\begin{array}{c}\text { No private school is } \\
\text { nearby vicinity }\end{array}$ & & & & & 100 \\
\hline $\begin{array}{c}\text { Distance private } \\
\text { school is too } \\
\text { expensive }\end{array}$ & & & & & 100 \\
\hline $\begin{array}{c}\text { Travelling for private } \\
\text { school is hectic for } \\
\text { children }\end{array}$ & & & & & 100 \\
\hline $\begin{array}{c}\text { Travelling for private } \\
\text { school is time } \\
\text { consuming }\end{array}$ & & & & & \\
\hline $\begin{array}{c}\text { Teachers response is } \\
\text { not good }\end{array}$ & & & & & & 100 \\
\hline
\end{tabular}

Table - 3D: Village Singhania

\begin{tabular}{|c|c|c|c|c|c|c|}
\hline Problems & $\begin{array}{c}\text { Most } \\
\text { Pressing } \\
(\%)\end{array}$ & $\begin{array}{c}\text { More } \\
\text { Pressing } \\
(\%)\end{array}$ & $\begin{array}{c}\text { Pressing } \\
(\%)\end{array}$ & $\begin{array}{c}\text { Less } \\
\text { Pressing } \\
(\%)\end{array}$ & $\begin{array}{c}\text { Least } \\
\text { Pressing } \\
(\%)\end{array}$ & $\begin{array}{c}\text { None } \\
(\%)\end{array}$ \\
\hline $\begin{array}{c}\text { No school is } \\
\text { nearby vicinity }\end{array}$ & & & & & & 100 \\
\hline $\begin{array}{c}\text { Teachers are not } \\
\text { localize }\end{array}$ & 14 & & & & & 86 \\
\hline $\begin{array}{c}\text { Not availability of } \\
\text { books in nearby } \\
\text { vicinity }\end{array}$ & & & & 14 & & 86 \\
\hline $\begin{array}{c}\text { No private school } \\
\text { is nearby vicinity }\end{array}$ & & & & & & 86 \\
\hline $\begin{array}{c}\text { Distance private } \\
\text { school is too } \\
\text { expensive }\end{array}$ & & & & & \\
\hline $\begin{array}{c}\text { Travelling for } \\
\text { private school is } \\
\text { hectic for children }\end{array}$ & & & & & & 86 \\
\hline
\end{tabular}




\begin{tabular}{|c|l|l|l|l|l|l|}
\hline $\begin{array}{c}\text { Travelling for } \\
\text { private school is } \\
\text { time consuming }\end{array}$ & & & & & & 100 \\
\hline $\begin{array}{c}\text { Teachers response } \\
\text { is not good }\end{array}$ & 14 & & & & 100 \\
\hline
\end{tabular}

Table - 3E: Village Undal

\begin{tabular}{|c|c|c|c|c|c|c|}
\hline Problems & $\begin{array}{c}\text { Most } \\
\text { Pressing } \\
(\%)\end{array}$ & $\begin{array}{c}\text { More } \\
\text { Pressing } \\
(\%)\end{array}$ & $\begin{array}{c}\text { Pressing } \\
(\%)\end{array}$ & $\begin{array}{c}\text { Less } \\
\text { Pressing } \\
(\%)\end{array}$ & $\begin{array}{c}\text { Least } \\
\text { Pressing } \\
(\%)\end{array}$ & $\begin{array}{l}\text { None } \\
(\%)\end{array}$ \\
\hline $\begin{array}{l}\text { No school is } \\
\text { nearby vicinity }\end{array}$ & & & & & & 100 \\
\hline $\begin{array}{c}\text { Teachers are not } \\
\text { localize }\end{array}$ & 12 & & & & & 88 \\
\hline $\begin{array}{c}\text { Not availability of } \\
\text { books in nearby } \\
\text { vicinity }\end{array}$ & & & 10 & 2 & & 88 \\
\hline $\begin{array}{l}\text { No private school } \\
\text { is nearby vicinity }\end{array}$ & & & & & & 100 \\
\hline $\begin{array}{c}\text { Distance private } \\
\text { school is too } \\
\text { expensive }\end{array}$ & & & 2 & 8 & 2 & 88 \\
\hline $\begin{array}{l}\text { Travelling for } \\
\text { private school is } \\
\text { hectic for children }\end{array}$ & & & & & & 100 \\
\hline $\begin{array}{l}\text { Travelling for } \\
\text { private school is } \\
\text { time consuming }\end{array}$ & & & & 2 & 10 & 88 \\
\hline $\begin{array}{l}\text { Teachers response } \\
\text { is not good }\end{array}$ & & 12 & & & & 88 \\
\hline
\end{tabular}

Table - 4: ANOVA

\begin{tabular}{|c|c|c|c|c|c|c|}
\hline & & $\begin{array}{l}\text { Sum of } \\
\text { Squares }\end{array}$ & Df & $\begin{array}{l}\text { Mean } \\
\text { Square }\end{array}$ & $\mathrm{F}$ & Sig. \\
\hline \multicolumn{2}{|l|}{ Education } & & & & \multirow{7}{*}{2.229} & \multirow{7}{*}{.066} \\
\hline & Between Groups & 7.708 & 4 & 1.927 & & \\
\hline 1. Problems/1ssues with & Within Groups & 214.410 & 248 & .865 & & \\
\hline educational racimtues & Total & 222.119 & 252 & & & \\
\hline No choolis moorchy & Between Groups & .000 & 4 & .000 & & \\
\hline 2. No school is nearby & Within Groups & .000 & 248 & .000 & & \\
\hline Vicinity & Total & .000 & 252 & & & \\
\hline \multirow{3}{*}{ 3. $\mathrm{Te}$} & Between Groups & 5.832 & 4 & 1.458 & \multirow[t]{3}{*}{5.575} & \multirow[t]{3}{*}{.000} \\
\hline & Within Groups & 64.863 & 248 & .262 & & \\
\hline & Total & 70.696 & 252 & & & \\
\hline \multirow[t]{4}{*}{4.} & Between Groups & 12.570 & 4 & 3.143 & \multirow[t]{3}{*}{4.375} & \multirow[t]{3}{*}{.002} \\
\hline & Within Groups & 178.133 & 248 & .718 & & \\
\hline & Total & 190.704 & 252 & & & \\
\hline & Between Groups & 6.419 & 4 & 1.605 & \multirow[t]{3}{*}{6.633} & \multirow[t]{3}{*}{.000} \\
\hline \multirow{2}{*}{ No private school is } & Within Groups & 60.000 & 248 & .242 & & \\
\hline & Total & 66.419 & 252 & & & \\
\hline \multirow{3}{*}{$\begin{array}{l}\text { sch } \\
\text { exp }\end{array}$} & Between Groups & 14.132 & 4 & 3.533 & \multirow[t]{3}{*}{3.091} & \multirow[t]{3}{*}{.017} \\
\hline & Within Groups & 283.433 & 248 & 1.143 & & \\
\hline & Total & 297.565 & 252 & & & \\
\hline \multirow{3}{*}{$\begin{array}{l}\mathrm{sch} \\
\mathrm{ch}\end{array}$} & Between Groups & 18.468 & 4 & 4.617 & \multirow[t]{3}{*}{6.437} & \multirow[t]{3}{*}{.000} \\
\hline & Within Groups & 177.880 & 248 & .717 & & \\
\hline & Total & 196.348 & 252 & & & \\
\hline \multirow{2}{*}{$\begin{array}{l}\text { Travelling for } \\
\text { school is time }\end{array}$} & Between Groups & 13.602 & 4 & 3.401 & \multirow[t]{2}{*}{4.939} & \multirow[t]{2}{*}{.001} \\
\hline & Within Groups & 170.753 & 248 & .689 & & \\
\hline
\end{tabular}




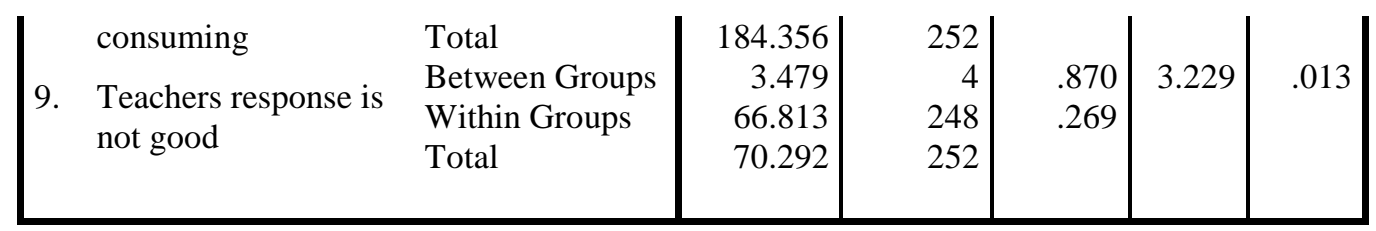

Table -5: Post Hoch TestsMultiple Comparisons

LSD

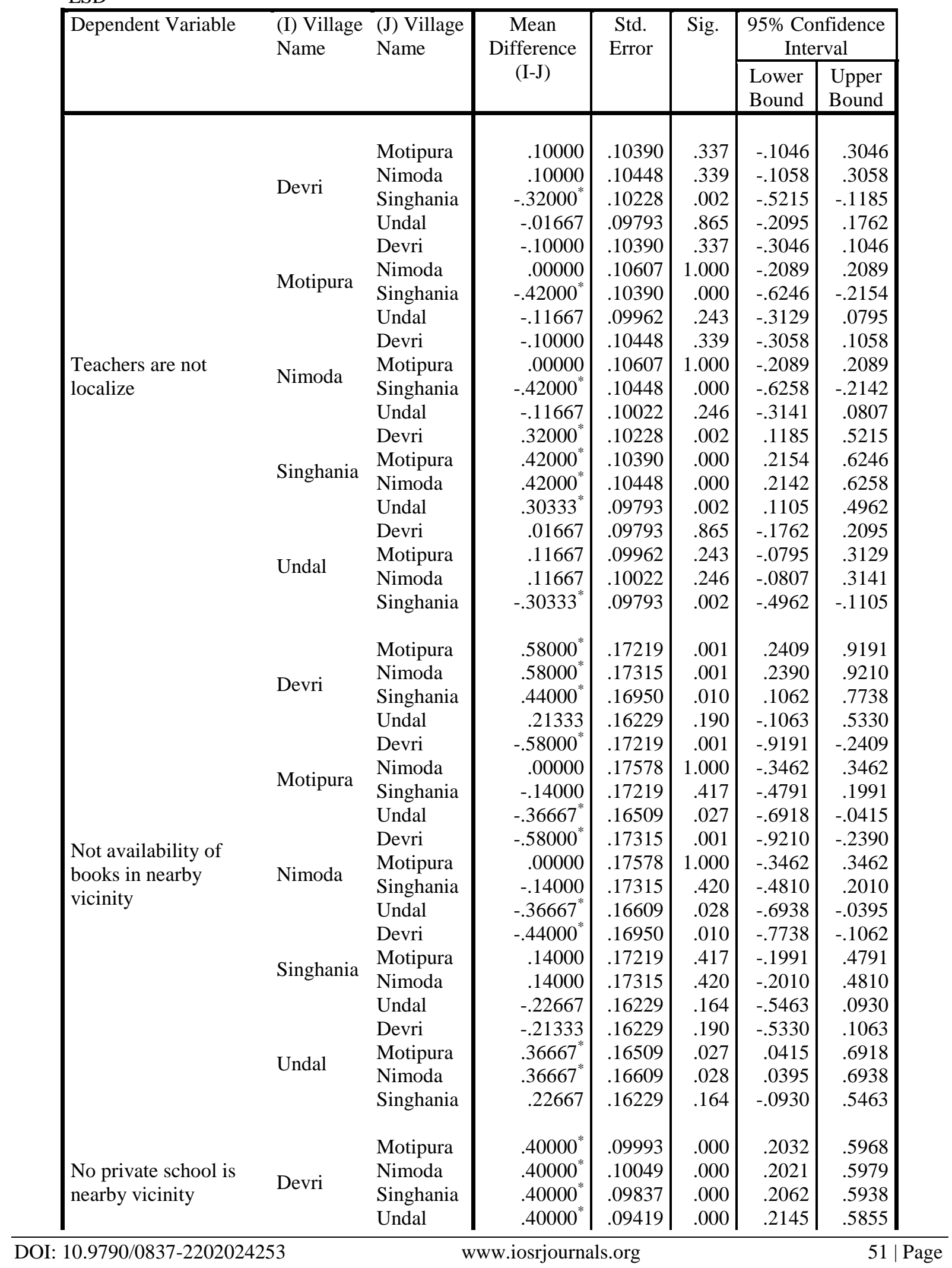




\begin{tabular}{|c|c|c|c|c|c|c|c|}
\hline & & Devri & $-.40000^{*}$ & .09993 & .000 & -.5968 & -.2032 \\
\hline & & Nimoda & .00000 & .10201 & 1.000 & -.2009 & .2009 \\
\hline & Motipura & Singhania & .00000 & .09993 & 1.000 & -.1968 & .1968 \\
\hline & & Undal & .00000 & .09581 & 1.000 & -.1887 & .1887 \\
\hline & & Devri & $-.40000^{*}$ & .10049 & .000 & -.5979 & -.2021 \\
\hline & & Motipura & .00000 & .10201 & 1.000 & -.2009 & .2009 \\
\hline & Nimoda & Singhania & .00000 & .10049 & 1.000 & -.1979 & .1979 \\
\hline & & Undal & .00000 & .09639 & 1.000 & -.1899 & .1899 \\
\hline & & Devri & $-.40000^{*}$ & .09837 & .000 & -.5938 & -.2062 \\
\hline & & Motipura & .00000 & .09993 & 1.000 & -.1968 & .1968 \\
\hline & singhanıa & Nimoda & .00000 & .10049 & 1.000 & -.1979 & .1979 \\
\hline & & Undal & .00000 & .09419 & 1.000 & -.1855 & .1855 \\
\hline & & Devri & $-.40000^{*}$ & .09419 & .000 & -.5855 & -.2145 \\
\hline & & Motipura & .00000 & .09581 & 1.000 & -.1887 & .1887 \\
\hline & Undal & Nimoda & .00000 & .09639 & 1.000 & -.1899 & .1899 \\
\hline & & Singhania & .00000 & .09419 & 1.000 & -.1855 & .1855 \\
\hline & & Motipura & .42000 & .21720 & .054 & -.0078 & .8478 \\
\hline & & Nimoda & .42000 & .21841 & .056 & -.0102 & .8502 \\
\hline & Devr1 & Singhania & -.14000 & .21381 & .513 & -.5611 & .2811 \\
\hline & & Undal & -.04667 & .20471 & .820 & -.4499 & .3565 \\
\hline & & Devri & -.42000 & .21720 & .054 & -.8478 & .0078 \\
\hline & & Nimoda & .00000 & .22172 & 1.000 & -.4367 & .4367 \\
\hline & Motipura & Singhania & $-.56000^{*}$ & .21720 & .011 & -.9878 & -.1322 \\
\hline & & Undal & $-.46667^{*}$ & .20824 & .026 & -.8768 & -.0565 \\
\hline & & Devri & -.42000 & .21841 & .056 & -.8502 & .0102 \\
\hline Distance private & & Motipura & .00000 & .22172 & 1.000 & -.4367 & .4367 \\
\hline school is too expensive & Nimoda & Singhania & $-.56000^{*}$ & .21841 & .011 & -.9902 & -.1298 \\
\hline & & Undal & $-.46667^{*}$ & .20951 & .027 & -.8793 & -.0540 \\
\hline & & Devri & .14000 & .21381 & .513 & -.2811 & .5611 \\
\hline & & Motipura & $.56000^{*}$ & .21720 & .011 & .1322 & .9878 \\
\hline & singnania & Nimoda & $.56000^{*}$ & .21841 & .011 & .1298 & .9902 \\
\hline & & Undal & .09333 & .20471 & .649 & -.3099 & .4965 \\
\hline & & Devri & .04667 & .20471 & .820 & -.3565 & .4499 \\
\hline & & Motipura & $.46667^{*}$ & .20824 & .026 & .0565 & .8768 \\
\hline & Undal & Nimoda & $.46667^{*}$ & .20951 & .027 & .0540 & .8793 \\
\hline & & Singhania & -.09333 & .20471 & .649 & -.4965 & .3099 \\
\hline & & Motipura & .18000 & .17206 & .297 & -.1589 & .5189 \\
\hline & & Nimoda & .18000 & .17303 & .299 & -.1608 & .5208 \\
\hline & Devr1 & Singhania & $-.52000^{*}$ & .16938 & .002 & -.8536 & -.1864 \\
\hline & & Undal & .18000 & .16217 & .268 & -.1394 & .4994 \\
\hline & & Devri & -.18000 & .17206 & .297 & -.5189 & .1589 \\
\hline & & Nimoda & .00000 & .17565 & 1.000 & -.3460 & .3460 \\
\hline & Motipura & Singhania & $-.70000^{*}$ & .17206 & .000 & -1.0389 & -.3611 \\
\hline & & Undal & .00000 & .16497 & 1.000 & -.3249 & .3249 \\
\hline & & Devri & -.18000 & .17303 & .299 & -.5208 & .1608 \\
\hline Traverming lor private & & Motipura & .00000 & .17565 & 1.000 & -.3460 & .3460 \\
\hline ildren & Nimoda & Singhania & $-.70000^{*}$ & .17303 & .000 & -1.0408 & -.3592 \\
\hline & & Undal & .00000 & .16597 & 1.000 & -.3269 & .3269 \\
\hline & & Devri & $.52000^{*}$ & .16938 & .002 & .1864 & .8536 \\
\hline & & Motipura & $.70000^{*}$ & .17206 & .000 & .3611 & 1.0389 \\
\hline & Singhanıa & Nimoda & $.70000^{*}$ & .17303 & .000 & .3592 & 1.0408 \\
\hline & & Undal & $.70000^{*}$ & .16217 & .000 & .3806 & 1.0194 \\
\hline & & Devri & -.18000 & .16217 & .268 & -.4994 & .1394 \\
\hline & & Motipura & .00000 & .16497 & 1.000 & -.3249 & .3249 \\
\hline & Undal & Nimoda & .00000 & .16597 & 1.000 & -.3269 & .3269 \\
\hline & & Singhania & $-.70000^{*}$ & .16217 & .000 & -1.0194 & -.3806 \\
\hline
\end{tabular}




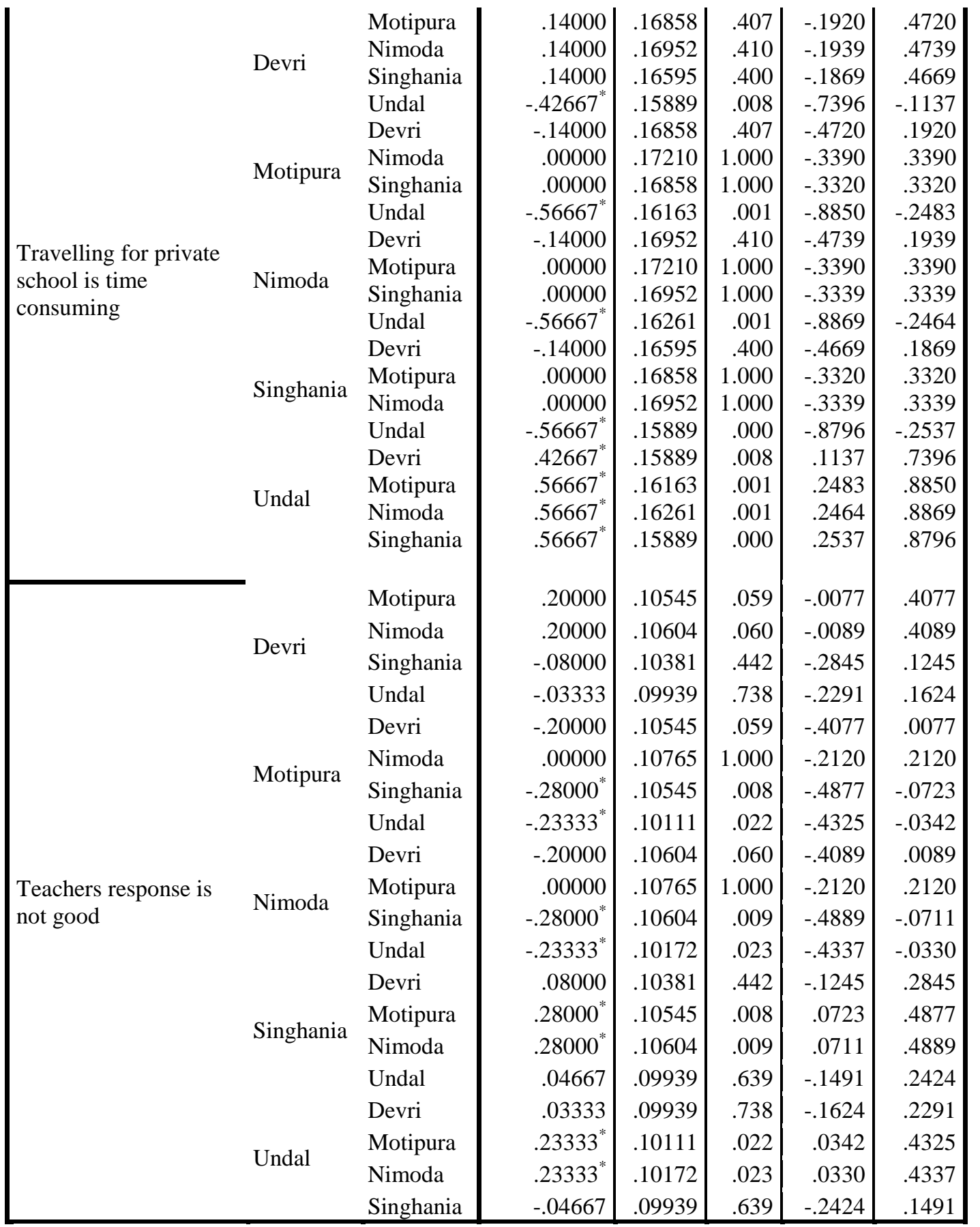

*. The mean difference is significant at the 0.05 level. 